\title{
Weight loss in primary biliary cirrhosis
}

\author{
G J BECKETT, N DEWHURST, N D C FINLAYSON, AND I W PERCY-ROBB \\ From the University Department of Clinical Chemistry and The Gastrointestinal and Liver Service, \\ Royal Infirmary, Edinburgh.
}

SUMMARY Duodenal bile salt concentrations were measured throughout one day in six patients with primary biliary cirrhosis while they were eating a normal ward diet. Five of them had lost weight; none had ascites. Each patient had a radiologically normal small bowel and a normal jejunal biopsy. No clear relationship between high faecal fat excretion and abnormally low duodenal bile salt concentration was found. Xylose absorption was abnormal in five patients. If weight loss in primary biliary cirrhosis is due to malabsorption, factors other than a reduced small intestinal bile salt concentration must be important.

Weight loss in chronic liver disease, including primary biliary cirrhosis, is often attributed to malabsorption, which is presumed to be due to a failure to achieve adequate bile salt concentrations in the small intestine. ${ }^{1}$ Van Berge Henegouwen et $a l^{2}$ showed that duodenal bile salt concentrations were diminished in primary biliary cirrhosis but were still significantly above the critical micellar concentration. ${ }^{3}$ In this study, cholecystokinin was used to stimulate the gallbladder and this procedure may not have produced duodenal bile salt concentrations similar to those which would be present in response to a normal diet. Westergaard ${ }^{4}$ used a standardised fatty meal as a stimulus to gallbladder contraction in patients with chronic liver disease and found that critical micellar concentrations of bile salts were not exceeded.

The purpose of this study was to further examine the proposal that malabsorption in primary biliary cirrhosis is due to inadequate duodenal bile salt concentrations. The duodenal bile salt concentrations were measured after ingestion of the normal hospital diet. The intestinal absorption of xylose was also studied.

\section{Methods}

\section{PATIENTS}

Six patients (five female and one male) with primary biliary cirrhosis were studied. Five had lost weight. Diagnosis was based on clinical features, biochemical cholestasis (Table 1), positive serum antimitochondrial antibody tests, and liver biopsy appear-

Received for publication 25 March 1980 ances compatible with primary biliary cirrhosis. Each patient had a radiologically normal small bowel, a normal jejunal biopsy, and a normal creatinine clearance. Schilling tests were performed on five of the patients and were normal in four of these. In one, patient $A$, the urinary excretion of vitamin $B_{12}$ was only $2.7 \%$ of the administered dose. The peripheral blood film was normal.

\section{PROCEDURE}

Jejunal and liver biopsies were performed on all patients before admission to hospital. All patients had taken oral cholestyramine before the study and this was discontinued seven days before admission.

On the day of admission, patients were started on a diet containing at least $70 \mathrm{~g}$ of fat per day, and a five day collection of faeces was begun. Blood was taken for estimation of plasma bilirubin, alkaline phosphatase (EC 3.1.3.3.), alanine aminotransferase (EC 2.1.6.1.2.), albumin, and creatinine. These measurements were carried out on a Technicon Sequential Multiple Analysis with Computer System (Technicon Instruments Company Ltd., Basingstoke, UK).

In the afternoon of the next day a single lumen tube was passed into the duodenum and its position checked by $x$-ray screening. Patients were fasted from $2200 \mathrm{~h}$.

At $0800 \mathrm{~h}$ on the next morning and every hour thereafter for approximately 14 hours, duodenal aspirate $(2 \mathrm{ml})$ was withdrawn for bile salt analysis. Patients ate the diet described above in the form of meals taken at recorded times. A 24 hour urine collection was carried out for creatinine clearance studies. 
Table 1 Liver function tests in patients with primary biliary cirrhosis

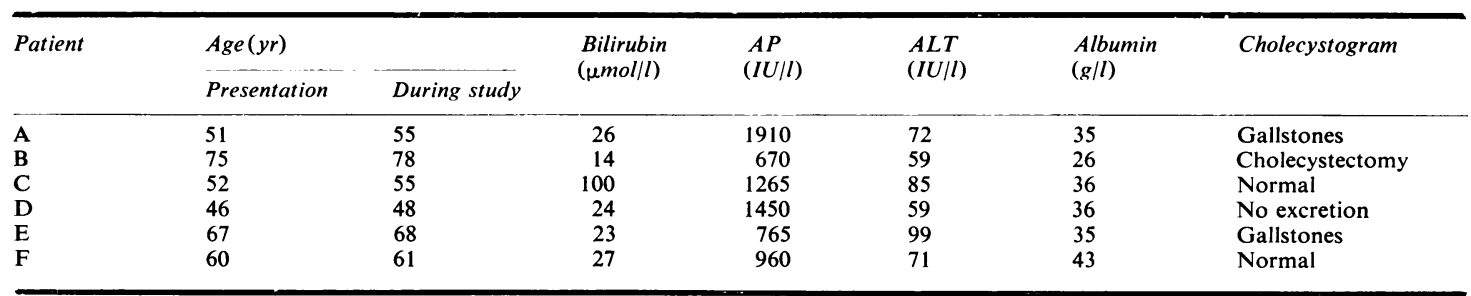

The table shows plasma concentrations of bilirubin, alkaline phosphatase (AP), alanine aminotransferase (ALT), and albumin in six patients with primary biliary cirrhosis. The reference ranges are bilirubin 2-17 $\mu \mathrm{mol} / 1$, AP 40-100 IU/1, ALT 10-40 IU/1, and albumin 36-47 g/l.

The urinary excretion of xylose over five hours was measured after an oral dose of xylose $(5 \mathrm{~g})$ on the fifth day. ${ }^{5}$ The faecal fat collection was concluded.

\section{DUODENAL BILE SALT CONCENTRATIONS}

Duodenal bile salt concentrations were measured by thin-layer chromatography followed by densitometry. ${ }^{6}$ This method separates the taurine and glycine conjugates of the dihydroxy and trihydroxy bile acids but does not differentiate conjugated chenodeoxycholate from conjugated deoxycholate.

\section{Results}

DUODENAL BILE SALTS

In four patients duodenal bile salt concentrations were below the lower limit of the reference range of $5.4 \mathrm{mmol} / \mathrm{l}^{4}$ but three of these never exceeded $1 \mathrm{mmol} / \mathrm{l}$ at any time during the day. Of the remaining two patients one achieved a maximal concentration of only $5.5 \mathrm{mmol} / \mathrm{l}$ (Figure).

\section{FAECAL FAT AND XYLOSE TESTS}

The faecal fat excretion was increased in five of the six patients, although in one (E) it was only marginally increased. The faecal fat excretion was normal in the one patient (D) who had not lost weight (Table 2).

There was no correlation between faecal fat excretion and duodenal bile salt concentrations. Two patients had normal duodenal bile salt concentrations and increased faecal fat excretions, and one patient had low duodenal bile salt concentrations and a normal faecal fat excretion. Xylose excretion was diminished in five patients.

\section{Discussion}

The formation of mixed micelles by conjugated bile salts, monoglycerides, and fatty acids is generally considered an essential step in the efficient absorption of dietary fat. The amount of lipid solubilised in micelles is proportional to the conjugated bile salt concentration, and this obtains even when the criti- cal micellar concentration has been exceeded; the amount of fat which can be solubilised increases by $40 \%$ as the concentration of bile salt rises from $4 \mathrm{mmol} / 1$ to $6 \mathrm{mmol} / 1 .^{78}$ It would therefore be reasonable to attribute the steatorrhoea commonly found in cirrhosis to inadequate duodenal bile salt concentrations, as bile salt synthesis is impaired and the bile salt pool size is reduced. ${ }^{9}$ In addition, there is a particular failure of bile flow in primary biliary

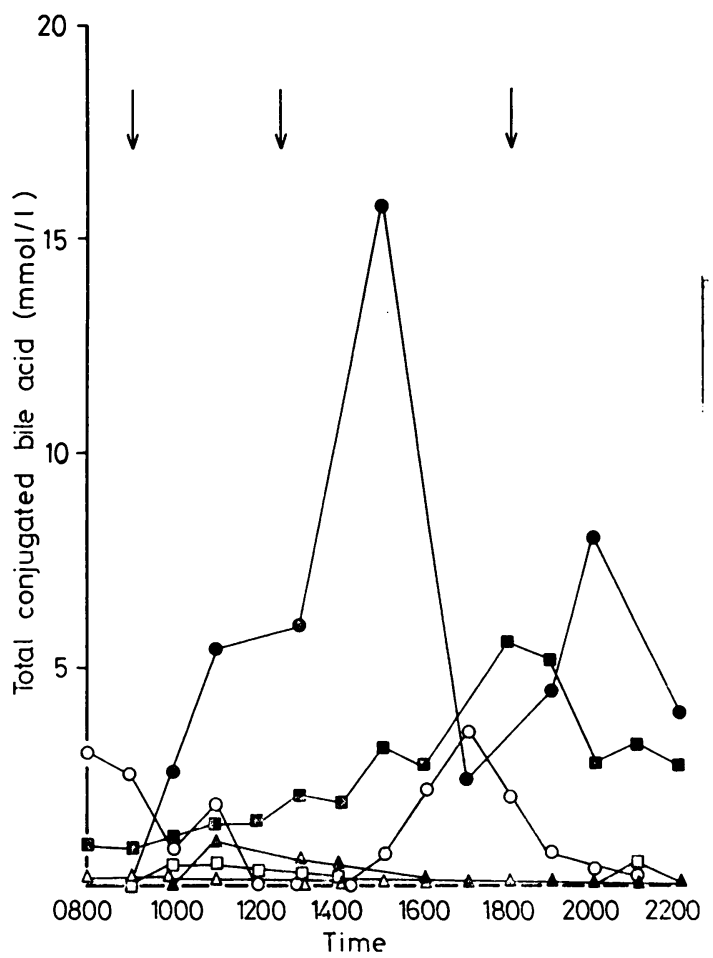

Figure Total duodenal bile salt concentrations in patients with primary biliary cirrhosis. Bile salt concentrations in duodenal aspirate were measured at the times shown in the figure using thin-layer chromatography. The patients (Table 1) are identified as follows- $(A \odot)(B \bigcirc)(C \triangle)(D \triangle)(E \square)$ and $(F \square)$. The arrows indicate the meal times. 
Table 2 Relationships between weight loss, faecal fat excretion, duodenal bile salt concentration, and jejunal absorption in patients with primary biliary cirrhosis

\begin{tabular}{|c|c|c|c|c|c|c|c|}
\hline \multirow[t]{2}{*}{ Patient } & \multirow{2}{*}{$\begin{array}{l}\text { Total } \\
(\mathrm{kg})\end{array}$} & \multicolumn{2}{|c|}{ Weight loss } & \multirow{2}{*}{$\begin{array}{l}\text { Faecal fat } \\
(\mathrm{g} / 24 \mathrm{~h})\end{array}$} & \multirow{2}{*}{$\begin{array}{l}\text { Maximum duodenal } \\
\text { bile salt } \\
\text { concentration } \\
(\text { mmol } / l)\end{array}$} & \multirow{2}{*}{$\begin{array}{l}\text { Xylose } \\
\text { test } \\
(5 \text { h excretion \%) }\end{array}$} & \multirow{2}{*}{$\begin{array}{l}\text { Stage } \\
\text { of } \\
\text { disease }\end{array}$} \\
\hline & & $\begin{array}{l}\text { Duration } \\
\text { (months) }\end{array}$ & $\begin{array}{l}\text { Rate } \\
(k g / y r)\end{array}$ & & & & \\
\hline $\begin{array}{l}\text { A } \\
\text { B } \\
\text { C } \\
\text { D } \\
\text { E } \\
\text { F } \\
\text { Reference } \\
\text { range }\end{array}$ & $\begin{array}{r}14 \\
6 \\
14 \\
6 \\
2\end{array}$ & $\begin{array}{r}24 \\
12 \\
24 \\
6 \\
12\end{array}$ & $\begin{array}{r}7 \\
6 \\
7 \\
12 \\
2\end{array}$ & $\begin{array}{r}9 \cdot 1 \\
24 \cdot 3 \\
46 \cdot 0 \\
3 \cdot 4 \\
5 \cdot 3 \\
7 \cdot 4\end{array}$ & $\begin{array}{l}15 \cdot 5 \\
3 \cdot 5 \\
0 \cdot 9 \\
0 \cdot 2 \\
0 \cdot 5 \\
5 \cdot 5 \\
5 \cdot 4-21 \cdot 5\end{array}$ & $\begin{array}{l}16 \cdot 3 \\
15 \cdot 8 \\
25 \cdot 5 \\
24 \cdot 2 \\
34 \cdot 6 \\
24 \cdot 8 \\
35\end{array}$ & $\begin{array}{l}\text { Early } \\
\text { Late } \\
\text { Late } \\
\text { Late } \\
\text { Late } \\
\text { Early }\end{array}$ \\
\hline
\end{tabular}

cirrhosis. While reduction of duodenal lipid solubilisation might explain the steatorrhoea observed in primary biliary cirrhosis, two of our patients (A and F) had a normal duodenal bile salt concentration and yet both of them had abnormal faecal fat excretion. Abnormal faecal fat excretion was also found in two of the remaining patients (B and $C$ ) and in these cases there were low duodenal bile salt concentrations. Our investigations indicate therefore that in patients with primary biliary cirrhosis accompanied by weight loss there is abnormal faecal fat excretion but the theory that this is solely attributable to a failure of lipid solubilisation by duodenal bile salts has not been confirmed.

Xylose absorption tests were performed in our patients and in five cases the absorption of this pentose was abnormal. In four of these the faecal fat excretion was also abnormal. A possible renal explanation for the abnormal xylose tests was apparently excluded by the observation that creatinine clearance was normal in each case. Ascites ${ }^{1011}$ or massive bacterial overgrowth ${ }^{12}$ in the proximal small intestine are also recognised causes of abnormal xylose tests. None of our patients had clinically recognisable ascites and the radiological appearances of the small intestine failed to reveal features associated with bacterial overgrowth: none of our patients received antibiotic therapy as a confirmatory test to rule out bacterial overgrowth in a definitive manner. Each of our patients had a histologically normal jejunal biopsy and an albeit uncommon association between normal biopsy appearances and abnormal xylose absorption has been previously reported, ${ }^{13}$ but not in patients with biliary cirrhosis. Xylose absorption is generally found to be normal in most cases of liver disease associated with hyperbilirubinaemia ${ }^{14}$ but studies in primary biliary cirrhosis do not appear to have been reported previously. The mechanism of the abnormal xylose absorption is not clear but it may be an important contributing factor to weight loss in primary biliary cirrhosis.
We would like to thank Pat MacDonald for her expert technical assistance. These studies were supported by grants from the Scottish Hospitals endowment Trust and the Mason Medical Research Trust.

\section{References}

${ }^{1}$ Sherlock S. Primary biliary cirrhosis (chronic intrahepatic obstructive jaundice). Gastroenterology, 1959; 37: 574-86.

${ }^{2}$ Van Berge Henegouwen GP, Brandt KH, Eyssen H, Parmentier G. Sulphated and unsulphated bile acids in serum bile and urine of patients with cholestasis. Gut, 1976; 17: 861-9.

${ }^{3}$ Hofmann AF. The function of bile salts in fat absorption. The solvent properties of dilute micellar solutions of conjugated bile salts. Biochem J, 1963; 89: 57-68.

${ }^{4}$ Westergaard $\mathrm{H}$. Duodenal bile acid concentrations in fat malabsorption syndromes. Scand $J$ Gastroenterol, 1977; 12: 115-22.

${ }^{5}$ Roe JH, and Rice EW. A photometric method for the determination of free pentoses in animal tissues. J Biol Chem 1948; 173: 507-12.

${ }^{6}$ O'Moore RRL, Percy-Robb IW. Analysis of bile acids and their conjugates in jejunal juice by thin-layer chromatography and direct densitometry. Clin Chim Acta 1973; 43: 39-47.

${ }^{7}$ Badley BWD, Murphy GM, Bouchier IAD, Sherlock S. Diminished micellar phase lipid in patients with chronic nonalcoholic liver disease and steatorrhea. Gastroenterology 1970; 58: 781-9.

${ }^{8}$ Van Deest BW, Fordtran JS, Morawski SG, Wilson JD. Bile salt and micellar fat concentration in proximal small bile contents of illectomy patients. $J$ Clin Invest 1968; 47: 1314-24.

${ }^{9}$ Vlahcevic ZR, Yoshida T, Juttijudata P, Bell CC Jr., Swell L. Bile acid metabolism in cirrhosis. III. Biliary lipid secretion in patients with cirrhosis and its relevance to gallstone formation. Gastroenterology 1973; 64: $298-303$

${ }^{10}$ Prokipchuk EJ, Bayless TM, Iber FL and Hendrix TR. Xylose absorption, distribution and urinary excretion in cirrhosis. (Abstract) Clin Res, 1961; 9: 331. 
${ }^{11}$ Marin GA, Clark ML, Senior JR. Distribution of $\mathrm{d}$-xylose in sequestered fluid resulting in false-positive tests for malabsorption. Ann Intern Med 1968; 69: 1155-62.

${ }^{12}$ Goldstein F, Karacadag S, Wirts CW, Kowlessar OD. Intraluminal small-intestinal utilization of d-xylose by bacteria. Gastroenterology 1970; 59: 380-6.

${ }^{13}$ Sladen GE, Kumar PJ. Is the xylose test still a worthwhile investigation? Br Med J 1973; 3: 223-6.

${ }^{14}$ Wilson FA, Dietschy JM. Differential diagnostic approach to clinical problems of malabsorption. Gasiroenterology 1971; 61: 911-31. 